\title{
Enhancing China's national image through culture festivals: A case study of China Culture Years in Europe
}

\begin{abstract}
:
Since the mid-2000s, the Chinese party-state has increasingly focused on pursuing cultural diplomacy abroad to improve its national image and gain or enhance cultural soft power. Although China’s cultural “Charm Offensive” has not gone unnoticed, a variety of specific activities have not been subject to research so far. This paper therefore attempts to fill this research gap by analyzing Chinese state-level cultural diplomacy through a comparative case study of three China Culture Year events held in France (2004), Italy (2010) and Germany (2012). These findings are subsequently compared to the China Culture Year in Australia (2012), thereby allowing the identification of spatial variations. I argue that the Chinese party-state applies a general approach of organizing the events abroad by making use of local institutions. At the same time, through the strategic selection of events, the festivals portray distinct national images that transmit particular narratives of self-presentation to the European audience and take into account country-specific preferences.
\end{abstract}

Keywords: China, Europe, cultural diplomacy, soft power, national images, China Culture Year

The Author:

Name: Christina Maags

Affiliation: Research fellow at the Goethe-University Frankfurt, Germany 


\section{Embarking on a cultural diplomacy mission}

In the age of expanding mass media and globalization, the generation of a positive international reputation is becoming increasingly important to nation-states. Since the launch of the Reform and Opening Policy in 1978 induced the political and economic rise of China, the Chinese party-state has also followed this trend. Yet, although China has invested heavily in generating a favorable reputation, its rise has not been gauged as a positive development. On the contrary, especially after the Tiananmen incident in 1989, international media and governments have interpreted China's rise as a potential "threat" [1:758] to regional and global security. The Chinese party-state hence has been concentrating heavily on improving its national image. As a result, the self-presentation of the Chinese party-state, which is eager to display itself in a positive light, stands in direct opposition to the often negative, even hostile, national images it is ascribed in the international realm.

In order to reduce this misalignment of national images, the party-state has since the mid-2000s embarked on a mission to improve its reputation abroad. In doing so it not only wishes to amend its reputation and portray its own views to a global audience, but also to generate "soft power," which refers to the realization of national goals in international relations through enhanced political, economic and cultural attractiveness [2:5-6]. In this context, Chinese ancient culture has been appraised as a particularly valuable soft-power resource by the party-state as well as Chinese and international academia. One prominent example of the promotion of Chinese culture abroad was the 2004 launch of the "Confucius Institute initiative,” which established a global network of Chinese culture and language institutes.

Despite an ample amount of research on this initiative, surprisingly little information has been generated concerning other activities such as Chinese cultural exchanges or festivals. This is astonishing since it is precisely an analysis of cultural festivals that would generate knowledge on what the Chinese party-state wants to demonstrate through the medium "Chinese culture” and which strategic approach it pursues in presenting this culture. To fill this research gap, this paper aims to answer the following questions: Firstly, which national cultural images and implicit selfpresentation narratives does the PRC attempt to transmit through Chinese cultural festivals in Western Europe? And secondly, which organizational approach can be identified behind the festivals? 
In order to answer these questions, the paper undertakes a comparative case study of state-led cultural festivals, so-called China Culture Years (CCYs), in Western Europe. Specifically, I compare the festival programs of three European China Culture Years - in France (2004), Italy (2010) and Germany (2012) - with the China Culture Year in Australia (2012). Through this case selection, continent-specific similarities and differences in the organization of the event as well as program content become observable. In particular, comparing the individual programs in great detail and thus identifying frequently offered cultural events allows for an interpretation of the national cultural images and underlying narratives of selfpresentation behind these events. On the basis of this study, I argue that the partystate disseminates diverging national cultural images to each target country examined depending on the tastes of the foreign audience at hand. In doing so it not only pursues political goals such as soft-power generation, but also aspires to display that China has overcome the historic "humiliation” it believes it suffered at the hands of foreign powers.

I support this claim by first familiarizing the reader with the international and domestic Chinese academic discourse on China's soft-power generation. For the purpose of helping the reader grasp the core concepts and theories used in this analysis, I explain this paper's understanding of soft power, cultural diplomacy and national images in general and show how the concept has been appropriated into Chinese rhetoric by the party-state. In the main part of the article I discuss the results of the comparative case study, retrace the organizational approach utilized, and identify strategic national cultural images and implicit narratives presented by the party-state. The paper wraps up with an evaluation of the strengths and weaknesses of this Chinese cultural diplomacy strategy as well as concluding remarks.

\section{Cultural attractiveness as a soft-power resource}

Since Nye coined the term "soft power" in 1990, which refers to "getting others to want the outcomes that you want" [2:5], the term has gained prominence among international scholars and media. In particular, the concept argues that governments may influence policy agendas in the international community by shaping the preferences of other nations through their own national attractiveness. Common softpower resources are culture, political values and institutions as well as policies which are regarded as legitimate [2:5-11]. 
Shortly after the emergence of the concept, the idea of improving China's international position through national image promotion was heavily debated in Chinese academia. Initial articles on how to formulate a "Chinese soft-power strategy” appeared in 1993. Here, Wang was the first Chinese scholar to regard Chinese culture as the most valuable resource [3:25] to diminish the emerging notion of the so-called “China threat.” The Chinese soft-power campaign, however, only became prominent in the mid-2000s [4:24] when Beijing initiated a multitude of campaigns to transmit positive national images. One example is the Chinese foreign policy of a "peaceful rise" (hépíng juéqi) (later coined the "peaceful path of development”) and a "harmonious world” (héxié shìjiè) of 2005 [5:193-198]. By incorporating ancient Confucian values into foreign policy, the party-state attempted to demonstrate its good intentions as a new major global player [6:76-81].

The beginning of China's pursuit of soft power, cleverly termed "China's Charm Offensive” by Kurlantzick in 2007 [7], triggered widespread debate in academia and the media [8;9]. In this debate, China's soft-power resources and strategies are believed to hold a number of potentials and limits. Besides the authoritarian character of its political system, limitations arise through China's growing hard power. While China is attempting to present itself as a benign power, its increasing military expenditure and its unwillingness to undertake fundamental political reform remain obstacles to the successful accumulation of soft power [9:28-30]. Yet, China's soft power can be seen as having profited from the decrease in US soft power over the last decade, with its comparative position strengthened internationally [10;11]. This development was made possible through China's strategic dissemination of positive cultural and economic national images, which have been utilized to cultivate foreign relations, especially with developing countries [12:53]. In this context, Chinese traditional culture is regarded as China's key cultural diplomacy resource by Chinese [9:25] and Western scholars [13:116] as well as the party-state.

The Chinese understanding of the term soft power (ruănshíli) is not necessarily the same as that in the Western discourse. While $\mathrm{Li}$, for instance, argues that Chinese academia strictly follows Nye's definition and emphasizes Chinese culture and foreign policy as primary soft-power resources, she also states that in the Chinese discourse the term has gone beyond this understanding and includes a variety of resources not mentioned by Nye, such as mass media, socioeconomic development 
or social cohesion and unity [9:25-28]. Kurlantzick supports this claim and states that the party-state mainly relies on its cultural and economic resources in its pursuit of soft power [7:6]. However, others indicate that the Chinese do not differentiate between soft and hard power at all but regard both powers as complimentarily contributing to China’s “comprehensive national strength” (zònghé guólì) [12:54].

Nevertheless, to accumulate soft power a nation needs to have favorable national images in the international community. When using the concept of "national images," this paper refers to Boulding's early idea of international reputation. According to Boulding, national images comprise the "total cognitive, affective and evaluative structure of the behavior unit or its internal view of itself and the universe" [14:120]. In this sense, there are two sides of national images. On the one hand, they are consciously developed by the nation-state, since they portray the nation and its opinion to a foreign audience in an attempt at self-presentation. On the other hand, national images constitute the sum of all associations made by other members of the international community, including subjective perceptions of the nation's strengths and weaknesses [14:120-121], which can never be fully overcome by national self-presentation.

In a manner comparable to advertising, strategic tools such as public and cultural diplomacy are commonly used to market an image globally [15:13-14]. Public diplomacy refers to governments' efforts to advance communication with a target audience in order to foster understanding of their countries' culture or national policies [16:3]. Depending on the definition some scholars also include non-state actors in their understanding of the term [17:7]. Activities that promote "cultural national images" abroad are part of cultural diplomacy, a subtype of public diplomacy [18:31-32]. However, the attribution of cultural diplomacy to public diplomacy is still subject to debate, as some scholars such as Aoki et al. rank cultural diplomacy among international cultural relations [19:212]. Nevertheless, this paper follows Cull's classification of cultural diplomacy since the author understands cultural diplomacy as a tool that influences international cultural relations.

Cultural diplomacy activities cover a wide range of campaigns and events. In general, they constitute a country's “attempt to manage the international environment through making its cultural resources and achievements known overseas and/or facilitating cultural transmission abroad” [18:32-33]. The goal of cultural diplomacy 
is thus to provide the target audience with an idea of a nation's culture by initiating culture programs, festivals, exhibitions or performances [20:1-9]. Although cultural diplomacy efforts may be conducted on a bilateral basis, they are often characterized as creating a "sender-message-receiver" relationship between the nation-state on the one hand and the foreign audience on the other [21:217]. Following Gienow-Hecht and Donfried, cultural diplomacy can be analytically divided into two approaches. The structural approach describes the preceding organizational and administrative procedures behind cultural diplomacy. Content and inherent "narratives" which are to be transmitted to the target audience are part of the so-called conceptual approach [22:16-17]. Based on the assumption of a "sender-message-receiver" relationship, this paper uses these two approaches to examine Chinese cultural festivals, as Figure 1 below illustrates. The Chinese nation-state uses cultural diplomacy to transmit strategic narratives of self-presentation to the target audience. Since every individual among the target audience holds a different attitude towards the sending nation-state, the cultural diplomacy measure leads to the creation of a variety of national cultural images. If the majority of these national cultural images prove to be favorable or positive, cultural soft power is accumulated.

Figure 1: The Generation of Cultural Soft Power through Cultural Diplomacy

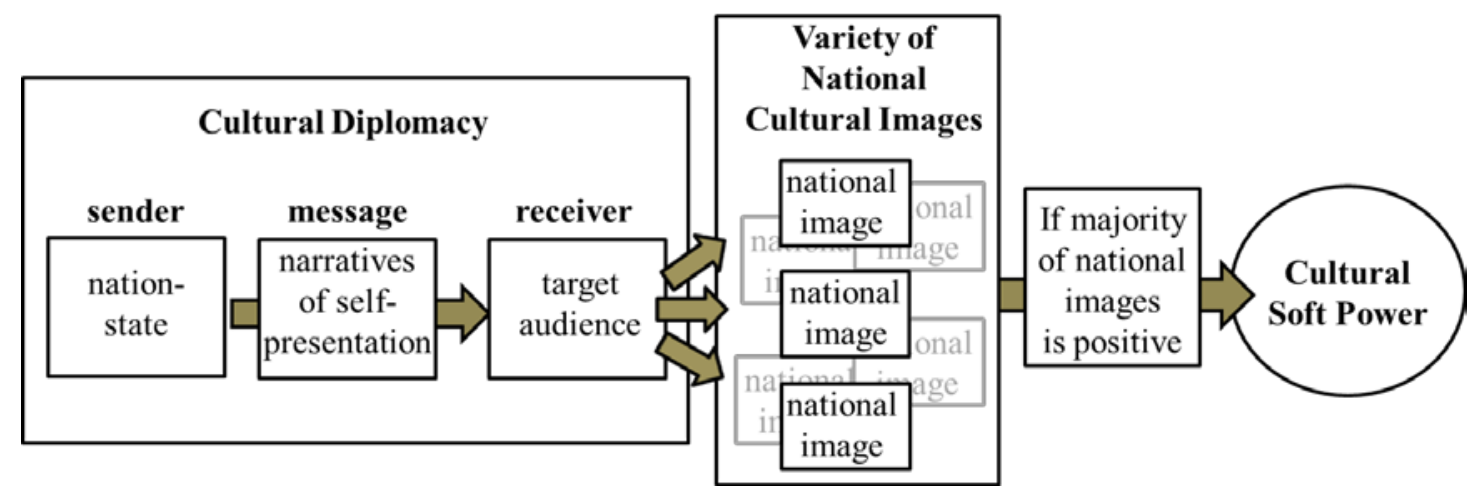

Source: Christina Maags

Although the PRC has expanded its use of cultural diplomacy, little is known about how China's cultural diplomacy measures are organized abroad and which narratives of self-presentation are intended for transmission. While Chinese scholars have produced an extensive literature focusing on the promotion of cultural soft power (wénhuà ruănshilì) through, for instance, China’s traditional culture [23] and cultural industries [24], international research on Chinese cultural diplomacy has been rather limited. The Confucius Institute (CI) initiative is the most prominent example of 
Chinese cultural diplomacy, as the number of institutes has skyrocketed in recent years and they demonstrate a strategic and efficient way of promoting Chinese culture abroad [25:70]. While the institute's role in promoting the Chinese language as a global language [26:80] has been acknowledged, it has also been compared to a "Trojan horse” which could exert Chinese influence in the West. This argument is supported by the fact that the CIs are initially financed by the party-state and are subject to Chinese law [27:259].

In addition to the Confucius Institute initiative, research has been conducted on a number of other Chinese cultural diplomacy activities. Firstly, the educational sector functions as a means of cultural diplomacy, since it not only depicts China as a new educational power but also familiarizes the incoming students with Chinese culture. For this reason, the party-state invests heavily to attract foreign students [28:111118]. Furthermore, touring artist troupes are organized to advertise Chinese culture abroad. In 2000, for instance, Zhang and Cameron examined an artist troupe campaign launched in the United States by the PRC and detected a positive shortterm influence on China's national image [29:24]. Finally, the party-state attempts to increase its exports of cultural products so as to enhance its cultural influence internationally and become a major “cultural power” [30:144-146].

In order to systematically examine Chinese cultural festivals, this study works inductively to generate hypotheses on the transmission of narratives of selfpresentation by the Chinese party-state through cultural festivals in Western Europe. As stated in the introduction, the study undertakes a comparative analysis of three Western European cases of the Chinese culture festival China Culture Year (CCY) in France (2004), Italy (2010) and Germany (2012). The findings of this analysis ${ }^{1}$ are then compared to a non-European case, the CCY in Australia, to identify potential spatial variations in the party-state's cultural diplomacy. The study utilizes the conceptual and structural approaches outlined above; these tools allow for an analysis of the festivals' organizational procedures as well as the national images portrayed through the program content. The paper's research design not only retraces the sender-receiver relationship, but also reveals country-specific narratives of presentation.

\footnotetext{
${ }^{1}$ The data set used in this study, which contains a list of all events, is available upon request.
} 


\section{Cultural diplomacy institutions, actors and policies in China}

After the founding of the People's Republic in 1949, Chinese traditional culture was repressed and replaced by "socialist culture" as a tool for cultural diplomacy. At first, Chinese socialist culture was only to be advertised to fellow socialist countries, yet later this practice was also pursued in connection with non-socialist countries [31:184]. With the Reform and Opening period, Chinese traditional culture was domestically revitalized and is still used as a means to strengthen national unity [ $32: 363$ ] and to counter the influence of Western culture. Internationally, the People's Republic has moved to intensively enhance bilateral cultural agreements since the late 1990s [33:1-16]. Thus there has been substantial support for cultural diplomacy activities, particularly since the mid-2000s [4:24].

This stronger emphasis on cultural diplomacy has found its way into various party documents and cultural policies. After the "Administrative Provision of Foreign Related Culture and Art Performances and Exhibitions” was issued in 1997 [34], regulating the conduct of Chinese cultural diplomacy abroad, a great variety of policies and provisions followed, particularly during the 2000s. With the beginning of the $\mathrm{Hu} /$ Wen administration, bilateral cultural diplomacy activities intensified. The new leaders supported cultural diplomacy by issuing a number of policies such as the “Formulation and Development of External Cultural Exchange Policy” in 2003 [35]. In 2006 the PRC announced the first "National Five-year Plan for Cultural Development," which promoted the export of Chinese cultural products [8:76]. In 2007, $\mathrm{Hu}$ explicitly set the strategic target of transforming China into a major cultural power [36]. Finally, the goal of advancing Chinese culture through a “cultural systems reform” (wénhuà tǐzhì găigé) was proclaimed during the Sixth Plenary Session of the Seventeenth CCP Central Committee in October 2011. During this event the Chinese party argued in favor of intensifying the reform domestically while simultaneously enhancing cultural soft power through the dissemination of Chinese culture abroad [37].

Responsibility for the formulation and implementation of concrete policies rests with a number of ministries and party organs that oversee policy enforcement. First and foremost, the Chinese Communist Party's (CCP) Central Publicity Department (zhōngyāng xuānchuán bù) and its many subsidiary offices monitor every area of internal (duìnèi) or foreign (duìwài) publicity. Here the CCP’s Office of External 
Publicity (zhōngyāng duìwài xuānchuán bàngōngshi) is of vital importance as it creates plans and guidelines for the development of public diplomacy, monitors foreign media and supervises domestic media. As the head of the Office of External Publicity is simultaneously the head of the State Council Information Office (SCIO), these party and state organs work together very closely [38:58-61]. In addition to this collaboration, many other state agencies cooperate closely with party organs in charge of safeguarding the correct implementation of policies by the state organs. Among the most important state agencies for the implementation of cultural diplomacy are the Ministry of Foreign Affairs (MFA), the Ministry of Education (MOE), the Ministry of Culture (MOC) [4:27-40] and the above-mentioned SCIO, all of which are directly subordinate to the State Council [39]. These agencies oversee affiliated departments directly engaged with cultural diplomacy. The Information Office (xīnwéns $\bar{l}$ ) under the Ministry of Foreign Affairs, for instance, supervises its own Public Diplomacy Office (gōnggòng wàijiāo bàngōngshi) [40], and the Ministry of Culture regulates its Bureau of External Cultural Relations (duìwài wénhuà liánluòjú) [ 41 ]. Yet, due to overlapping jurisdictions, the responsibilities of the individual state and party authorities remain blurred and a potential source of conflict [42:31-32]. Furthermore, the work of these authorities is supported at the grassroots level by government-organized nongovernmental organizations (GONGOs) such as the Chinese People Association for Friendship with Foreign Countries (CPAFFC), initiated in 1954 [ 43 ], and the China International Cultural Association (CICA), set up in 1986 [44].

\section{Beating the big drum for Chinese culture in Europe}

Since the early 2000s, the PRC and Western European states have begun to strengthen their cultural ties by engaging in reciprocal cultural diplomacy. Europe and China have a reciprocal interest in maintaining good foreign relations with their key partners in trade. However, their relations are frequently subject to conflicts in the political arena [12:147-54]. European countries and the PRC therefore both pursue cultural diplomacy in order to enhance cooperation and strengthen political ties through culture. Another motivation for the Chinese party-state is its wish to improve its national image among European citizens by spreading and marketing Chinese culture. Since "China wants to be acknowledged and respected as an ancient 
but vibrant culture” [13:167], the global spread of its cultural values is of vital importance to the PRC [13:167-68].

Despite China's negative political national image in Europe, its rise triggered a strong interest in the People's Republic among European citizens. This trend led to an increased demand for activities such as Chinese language training, cultural events and exhibitions, something which the party-state is eager to nourish [13:163]. Between 2004 and 2013 Hanban (Confucius Institute Headquarters) established 140 Confucius Institutes and 126 Confucius Classrooms in 35 European countries and regions [45]. In addition to the CI initiative, China Culture Centers (CCCs) have been established worldwide, also offering a multitude of language classes and cultural events. To date three centers have been opened in Europe: Paris, Malta and Berlin [46]. Along with these activities, based in the target country, a variety of academic exchange programs have been set up to increase the number of foreigners visiting China to learn about Chinese language and culture [9:18-19].

In addition to the unilateral promotion of Chinese culture abroad, the PRC also engages in cooperative cultural diplomacy. Since 2004, bilateral "Culture Years" have been organized with a growing number of European states. As part of this cultural diplomacy, the People's Republic is invited to demonstrate its national culture to the national audience; the partner country then presents its culture to the Chinese audience [47]. In Western Europe, three so-called China Culture Years have been held to date: France (2003) [48], Italy (2010) [49], Germany (2012) [47].

\section{The China Culture Year in France (2004)}

In Western Europe, France has historically played the role of a vanguard in building relations with the PRC. It was the first Western European country to establish diplomatic relations with the party-state in 1964, and the subsequent bilateral cultural agreement of 1980 officially established cultural relations. Since then, China and France have successfully organized numerous cultural events such as the China Cultural Week in Paris in 1999. The reformulation of the French-Chinese cultural agreement in 2002 further expanded these efforts by including the construction of mutual cultural centers in its objectives [33:14-15]. During the reformulation of the new cultural agreement, the two countries agreed to organize a mutual Culture Year in the near future. France thus became the first European country to hold a China 
Culture Year, from 2003 to 2004; a French Culture Year in China from 2004 to 2005 followed [48]. Due to the French role as a vanguard and the potential learning effect for Chinese organizers, the French CCY can be interpreted as providing the "blueprint” for subsequent CCYs in Europe, since it provided opportunities to experiment with organizational procedures as well as program content for later CCYs.

Officially, representatives of the French and Chinese governments mutually organized the CCY by establishing a joint organizing committee. However, in most cases it was the Chinese Ministry of Culture, its subordinate agencies [48] and GONGOs such as the China International Culture Exchange Center (CICEC) (Zhōngguó guójì wénhuà jiāoliú zhōngxīn) [50] that acted as the main organizers. Events such as the Film Week were organized by the Chinese and French agencies as follows: the Sino-French Cultural Association cooperated with the Chinese Ministry of State Administration of Radio, Film, and Television (SARFT), thereby ensuring Chinese agencies' ability to determine the event's content. In addition to ministries, the cultural bureaus of Chinese municipalities party to "twinning" agreements with a French town or province also assisted with the organization. Finally, the Chinese Culture Center located in Paris, which was the first of its kind to be established in Europe, in 2002 [51], also supported the planning and organization of the CCY [52].

The French CCY was structured according to four major themes: The first, "Eternal China," comprised eight exhibitions on manifestations of Chinese traditional culture such as the Dunhuang site or Jingdezhen porcelain [48]. Here, the name "Eternal China” hinted at the longevity of the Chinese empire, which not only endured for 5000 years but will also continue to prevail. The second theme, “China's Traditions and Diversity,” was covered in eight events related to Chinese daily life, including Chinese gardens, music and traditional dance [48]. Although this theme featured Chinese traditional culture as the first theme, the narrative behind the name implied that Chinese culture is not only eternal but also rich and diverse. The organizers offered nine events on contemporary art, photography and cinema as a part of the third theme, "Chinese Creators and Modernity," thereby suggesting that Chinese culture is modern and innovative and thus comparable to Western culture. Finally, theme four, “Twin Towns," presented French cities that had signed a twinning 
agreement with a Chinese town [48], thereby displaying Sino-French municipal and provincial cultural cooperation. In total, the 35 cultural events represented an equal selection of contemporary and traditional Chinese culture.

Despite the focus on Chinese culture, the organizers also included two fashion shows as part of the theme "Chinese Creators and Modernity." These events stick out since they did not have an obvious connection to Chinese culture itself. However, since fashion is a common association made with France, these events can be seen as having been incorporated in order to cater to target audience preferences. This indicates that the CCY organizers intentionally included events that would appeal to the target audience in order to attract a greater number of visitors.

The China Culture Year in Italy (2010)

Equally interested in China's reform and opening up, Italy has also pursued the advancement of cultural relations with the PRC. After the Italian government established diplomatic relations with the People's Republic of China in 1970, the two states signed an agreement on cultural cooperation in 1978 [33:7-8], which also included the establishment of 40 provincial and municipal twinnings [53]. Since 1999 China and Italy have engaged in more extensive cooperation, organizing cultural exchanges such as the Sino-Italian "Cultural Cooperation Plan” from 20042007 [54]. More recently an executive program focusing on cultural collaboration between China and Italy was established for the period 2009-2012 [53:10].

The China Culture Year in Italy (October 2010-November 2011) represented this stronger emphasis on cultural cooperation. In the preparation of this event to commemorate the fortieth anniversary of the establishment of diplomatic relations, the MOC and its affiliated institutions again functioned as the main organizers. Municipal and provincial governments in Italy and China supported the ministry and participated in the preparation of cooperative projects. One example is the provincial government of Anhui, which not only organized the event but also sent its vicegovernor, Hua Jianhui, and a delegation of 130 government and local business representatives to attend Anhui Week [55]. Finally, local Chinese cultural institutes and associations assisted with the organization [49]. 
During the Italian CCY, 45 major events took place across the country. In contrast to the French CCY, the organizers did not assign the events to a number of themes but merely listed them according to their date. This design implies that the original use of themes as applied in the blueprint was gauged as unsatisfactory. Furthermore, the distribution of events revealed a comparatively stronger focus on contemporary culture, which accounted for 57.7 percent of the program in comparison to traditional culture events at 26.6 percent.

Great emphasis was placed, firstly, on the display of Sino-Italian historical encounters and cultural cooperation projects, with such content accounting for 20 percent of the program. Moreover, the CCY organizers highlighted exhibitions of contemporary art, which made up 17 percent of the content, suggesting that they expected a strong interest in these events on the part of the Italian visitors.

In addition to these culture-related events, 15.5 percent of the program content consisted of scientific or technological events such as the "Chinese-Italian Forum on Innovation” or the Conference on Water, Renewable Energy and the Use of Thermal Energy. In fact, the organizers incorporated seven events that went beyond the realm of culture and referred to China's economy, its tourism sector, and environmental protection, as well as its banks and financial institutions [49]. By incorporating narratives regarding Chinese innovative industries and sustainable development, these events directly referenced the concept of the "Scientific Outlook on Development” (kēxué fāzhăn guān) announced in 2004. This concept argued that the PRC needs to achieve a development model focused not only on economic growth but also on socially acceptable and sustainable development [56]. The organizers' use of a domestic Chinese concept in cultural diplomacy suggests that they were attempting to promote this narrative in Western Europe and foster Sino-Italian industrial collaboration. In this context, local enterprises acting as representatives of the PRC's industry were particularly advertised. This is exemplified by the Anhui province delegation, which presented 200 projects worth US\$83.5 billion of investment during Anhui Week [55]. Like the French CCY, the Italian case can thus also be regarded as being tailored to the Italian target audience, not only taking the general public's interest into account but also catering to the interests of entrepreneurs and officials. 
The China Culture Year in Germany (2012)

The Sino-German (FRG) agreement on cultural cooperation in 1978 paved the way for greater German cultural involvement through the establishment of Goethe Institutes or the German Academic Exchange Service (DAAD) in China. As a result of the initiation of a new cultural exchange program in 1993, bilateral cultural ties were further strengthened. As part of the party-state's enhanced emphasis on cultural diplomacy, the PRC organized a Chinese Week in Germany in 2001, the largest event of its kind in Europe until then [33:11-15]. Later, in 2005, the two nations signed a new cultural cooperation agreement that emphasized the promotion of cultural awareness in each other's countries as well as the fostering of cultural, educational and scientific exchange [ $57: 37]$. In order to celebrate the fortieth anniversary of the establishment of diplomatic relations, the PRC again proposed a China Culture Year for Germany in 2012 [47], thus expanding the presence of CCYs in Europe.

As in France and Italy, the Chinese party-state kept to its strategy of formally arranging the festival during meetings with high-ranking state representatives and utilizing the MOC to plan the event through its cooperation with a Sino-German organization committee. In addition, other organizers officially contributed to the event, namely, German and Chinese cultural institutions such as the Goethe Institute, the Confucius Institutes, the China Culture Center in Berlin, and twin cities, as well as a number of museums and academic institutions. It is also noteworthy that in the German CCY a large number of companies were explicitly listed as sponsors of the event, something that implies increased attention to the incorporation of Chinese and German enterprises in the festival. Examples include the Gabriele Minz GmbH and the Volkswagen AG as well as TV stations such as ARTE TV and RTL TV [47].

In contrast to the Italian CCY, the organizers again arranged the German CCY according to five themes; however, they did not include implicit narratives in the names. As a part of the first theme, "Music," the organizers set up ten events on classical Western, traditional and popular music. Contemporary culture as manifested in photography, sculpture or architecture was portrayed in theme two, "Arts and Design,” which comprised 19 events. The third theme, “Cultural Dialog,” discussed Sino-European interactions in six events referring to education, scientific exchange and the implications of the Chinese rise. Theme four, "Theater and Dance," consisted 
of six modern and traditional theater and dance performances. Finally, the fifth theme "Special Projects," focused on twinning projects and the CCC in Berlin, illustrating Sino-German cooperation through 17 events. Similarly to the Italian case, the distribution of the 58 events also shows a greater emphasis on contemporary Chinese culture (56.9 percent), especially in the form of art exhibitions, classical musical performances, and Chinese architecture and design [58].

If we compare the German CCY to the previous cases, the program again demonstrates a focus on country-specific content. The organizers firstly highlighted contemporary music, art and architecture, suggesting that they assumed a stronger interest in these areas among the German target audience. In addition, the events for the themes "Cultural Dialog" and "Special Projects" particularly illustrated SinoGerman scientific, economic and cultural cooperation, promoting China as a valuable partner in these areas. Hereby the party-state again accentuated China's innovative industry and sustainability through the incorporation of scientific and technological events; however, as it displayed these events through Sino-German cooperative projects, an emphasis was put on the mutual benefit arising through the Chinese rise instead of merely advertising Chinese industry [58].

\section{The China Culture Year in Australia (2012)}

After the Australia-China Council (ACC) was established in 1978, the two nations launched many cultural projects to enhance people-to-people relations [ 59 ]. Following the initial bilateral cultural agreements between China and Australia in 1981, the two countries agreed to establish a number of programs under the Agreement on Cultural Cooperation - most recently the Cultural Exchange Program, which came into being in 2012. The latter program resulted in an increase in cultural exchange projects for the period 2013-2015 [60]. In addition, the Year of Chinese Culture in Australia (YCCiA) - “Experience China” (from June 2011 to June 2012) formally celebrated the fortieth anniversary of Sino-Australian diplomatic relations [61].

Again it was the MOC and the cultural office of the Chinese Embassy in Australia that mainly carried out the organization of the festival. On behalf of the Australian government, the Department of Foreign Affairs and Trade, the Department of the Prime Minister and Cabinet and the municipal government of Sydney contributed to 
organizing the event. Moreover, a multitude of companies acted as official sponsors. Next to Chinese companies such as Huawei, Air China, China Southern and Sinopec, Australian companies including Rio Tinto, ANZ, and Telstra also sponsored the festival [61].

The Australia CCY followed the slogan "Experience China." The organizers thus designed the event to offer the target audience the opportunity to discover China and to form its own opinion on the country. In particular, the organizers structured the program and its 45 events into seven neutrally formulated themes: The first theme, "Visual Arts," comprised ten main events displaying exhibitions of Chinese traditional and contemporary arts as well as designs. Introducing Chinese "Music," the second theme, consisted of five performances of classical music, traditional Chinese instruments and Inner Mongolian traditional music. Four main events dealing with the medium "Film" were the topic of the third theme, which presented, among other films, the founding of China in Beginning of the Great Revival. As part of themes four and five, “Theatre” and "Dance,” five modern theater events and five contemporary and traditional dance events took place. The sixth theme, "Literature," only comprised one event, namely, a three-week-long book fair called "Discovering China.” Finally, the seventh theme, "Others,” consisted of ten miscellaneous events such as dance and classical music [62]. This distribution again concentrated on contemporary culture, which accounted for 62.2 percent of the events. In sum, the majority of events involved theater or contemporary art and design.

The Australian CCY demonstrated a slightly different focus from the European cases. Firstly, the Australian case incorporated a greater number of events related to Chinese "popular culture," such as modern theater, film and sports. This focus could be due to the large proportion of Australian citizens of Chinese descent who are strongly interested in Chinese popular culture [63:77]. Again, the program content seems to have been tailored to the taste of the target audience. Secondly, events relating to Tibetan and Mongolian culture were represented in Australia, while they were absent in all European cases. This finding shows that the Chinese party-state was reluctant to demonstrate China's ethnic minority culture to European citizens, while it did not hesitate to display this content to an Australian audience. This suggests that the PRC expected a less critical response from the Australian audience on this sensitive issue. 


\section{China's cultural self-portrait in Europe}

\section{Structural approach}

If we reconstruct the party-state's procedure for implementing CCYs, we find that three steps are characteristic in the negotiation and organization of the cultural festivals. Firstly, the party-state makes use of state-level diplomatic events to address the intent of organizing a mutual state-level cultural festival. One strategic element common to all cases examined here was the proposal to hold the event in the year of the fortieth anniversary of the establishment of diplomatic relations with the country in question, thereby sending a strong symbolic message of friendship and cooperation to the target audience.

Secondly, following the official agreement to organize such an event, the party-state triggers a multi-actor and multi-level mechanism inside and outside of China. At the state level, the Ministry of Culture and its subordinate bureaus are most actively engaged in organizing and sponsoring the event. In many cases the MOC presents itself as the main organizer of the CCY and is listed as the contact agency for further inquiries [64]. Next to state-level cultural institutions, the cultural bureaus at the provincial and municipal levels support the organization process, particularly through their twinning relationships. Besides Chinese agencies operating from China, various actors and their local networks in the target country offer a valuable access point for the implementation of the CCY's program. Along with the cultural bureaus of the Chinese embassies, the newly established China Culture Centers and Confucius Institutes play a leading role in organizing and fine-tuning the festival to local preferences [65:3] and often provide the venues and staff for holding CCY events. Ultimately, despite the fact that they work in cooperation with target-country representatives, the Chinese organizers strongly influence program content, thereby communicating strategic national images and narratives of self-presentation to the target audience.

\section{Conceptual approach}

In addition to a common structural approach, the European cases also demonstrate clear commonalities in the conceptual approach. All European CCYs analyzed included a blend of events relating to contemporary and traditional Chinese culture. Among the cultural events, a package with “core events” constituted the integral part 
of the program. Events shown in all European cases analyzed were as follows: modern ballet, classical music and contemporary art exhibitions. Additionally, the organizers tailored the program according to the respective target audience's tastes so as to make the program more appealing to the visitors. While the French CCY presented two events related to fashion, the Italian case included a great emphasis on cultural and economic cooperation. The German case focused heavily on contemporary music as well as architecture and design. D’Hooghe’s [13:168] and Li's [65:3] argument that cultural diplomacy activities by the party-state are "finetuned" to local tastes is thus supported by this study, which suggests that the inclusion of local preferences is an integral part of the China Culture Year program.

Despite many similarities, the CCYs also differed on certain accounts: Firstly, although the French CCY provided the blueprint and demonstrated an equal share of 50 percent traditional and 50 percent contemporary culture, the subsequent cases offered a disproportionate amount of contemporary culture, ranging from approximately 57 to 63 percent. Secondly, in some cases the "core program” was further extended by additional scientific-technological or economic content of approximately 5 to 15 percent. As this extension was part of both the Italian and German cases, one can presume that the PRC's advertisement of its "sustainable development" and "innovativeness" were later included in the CCY blueprint for European cases. These findings are in line with previous studies illustrating the Chinese strategy to generate soft power by simultaneously investing in its economic and cultural national images [63:86]. Finally, subsequent organizers omitted specific design elements or added new ones to the blueprint, such as descriptive theme names or slogans. This indicates that although the majority of the blueprint characteristics were maintained, the organizers also further developed the CCY design over the years.

If we compare the European cases to the Australian case, we find that the latter shows a similar structural and conceptual approach. As in the German case, the organizers not only chose a strategic slogan for the Australian CCY, "Experience China," deploying it as a means of transmitting narratives of self-presentation, but also divided the events into neutrally formulated themes. Like the Italian and German cases, the organizers put a stronger emphasis on contemporary culture (55.6 percent). 
Lastly, the Australian program incorporated country-specific content, illustrating the aim of interesting the Chinese diaspora in Australia [66].

While all the European cases included traditional Chinese opera, national orchestra concerts, events related to higher education, these were not included in the Australian CCY. Here the organizers put a greater focus on popular culture such as movies or martial arts. As stated above, a possible motivation to include popular culture could have been the larger number of Australians of Chinese descent who are more familiar with and interested in current Chinese pop culture [63:77]. Another divergence in the Australian case was events related to ethnic minority culture, such as exhibitions of Tibetan paintings and Mongolian music. The inclusion of this content could be explained by Australia's historical experiences with its own ethnic minorities, which may have led to the reasoning that Australians would be less critical about this issue. An additional motivation could have been that the large number of visitors of Chinese descent would expect Chinese culture to also include its ethnic minority cultures. Finally, content referring to the PRC's innovativeness or sustainability was entirely absent in the Australian CCY, while two out of three European cases witnessed a great number of such events. This finding is astonishing since Australia is also an important trade partner of the PRC [67]. One explanation could be that because the Australian public has held a more favorable opinion of China over the last decade than, for instance, Germany or Italy, which hold the least favorable opinions among European countries [68], the Chinese organizers opted to use a combined soft-power approach in Europe - using economic and cultural resources but regarded cultural resources as sufficient in Australia.

\section{Narratives of self-presentation in cultural national images}

On an implicit level, the CCY theme names, festival slogans and individual events are tools to transmit strategic narratives of self-presentation to the target audience. During the first French CCY, which provided the blueprint for subsequent CCYs, the program coordinators chose to use theme names. The first theme, "Eternal China," evoked a picture of the Chinese state's longevity that demonstrated China's selfconfidence, cultural superiority and equality to Western powers. The second theme "China's Traditions and Diversity," pointed to the magnitude of diverse Chinese traditions. Surprisingly, however, only Han-Chinese traditions were included in the theme. This narrative implied that there is a great diversity in Chinese culture 
without explicitly mentioning ethnic minority cultures. By referring to "Chinese Creators and Modernity," the third theme, the party-state underlined China's progress and innovativeness. However, no reference was made to technological innovation, with only cultural events such as orchestras or ballet performances included. The fourth theme, “Twin Towns,” portrayed concrete examples of cultural cooperation between China and the target country, thus presenting China to the visitors as a cooperative and responsible partner.

The use of festival slogans in subsequent CCYs, was a second means of transmitting implicit narratives of self-presentation. For instance, in the German case the slogan "CHINAH" was used, an amalgamation of the German words for "China" and "Near". This suggested that China is a close friend that needs to be experienced in order to be fully understood. Moreover, this narrative revealed the Chinese intent to make Chinese culture and values more accessible to the target audience and counter international criticism against China. The narrative furthermore directly coincided with the PRC's official statement of attempting to foster a better understanding of China and its citizens abroad [69], as well as with the unofficial goal of making its own opinion heard internationally [70:256].

The distribution of particular types of events within a CCY has been a third means to transmit specific national images and narratives of self-presentation to the European audience. Firstly, the extensive incorporation of modern ballet, classical music and contemporary art exhibitions indicates that the Chinese party-state wants to present the national image of China's "high culture” (in contrast to popular culture). Since these events are classic examples of Western "sophisticated culture" [71:329-380], this narrative suggests that Chinese culture is also to be regarded as "high culture" on par with Western culture. This intent could be based on the notion that China has undergone "a century of humiliation” [72:200-201] at the hands of Western powers, which is being redressed today by China's national strength. Finally, the PRC's goals of offering an alternative to Western culture and demonstrating a superior national culture [9:27-28] coincide with such displays of "high culture."

Secondly, the omission of ethnic minority culture in the European examples reveals that the Chinese party-state intentionally did not highlight the existence of such culture in Europe, while it did so in the Australian context. This suggests that the party-state attached greater importance to portraying cultural unity to the European 
audiences than in Australia, where even the opening ceremony, "The Legend of Shangrila,” exhibiting ethnic minority culture [67] referred to Tibetan culture. This restricted mode of self-presentation in Europe could, on the one hand, have been grounded in the strong European advocacy of human rights and democratic values [13:167-68]. On the other hand, Australia's experience with its own ethnic minorities may have motivated China to more strongly represent its ethnic minority cultures in this case. All in all, as Chinese scholars view the portrayal of social cohesion and unity as an element of soft power, the national image of "cultural unity" further substantiates Chinese soft power.

Thirdly, the explicit inclusion of events highlighting Chinese innovativeness in the European cases not only reflects China's unorthodox approach of using cultural resources in combination with economic resources for soft-power accumulation but also indicates its attempt to portray an "innovative" China. As the European countries examined are important trade partners for China, the implicit advertisement of China's innovativeness could have been intended to further boost economic trade and foster trust in the Chinese economy. Furthermore, by linking Chinese innovativeness with twinning events, the PRC promoted location marketing in the individual European countries, which compete against each other for shares of the Chinese market. Jia argues that an economic platform is advantageous for the diffusion of Chinese culture through cultural products; while on the other hand Chinese national images are promoted on a cultural platform [73:13]. Or to use Hartig's words: “Chinese culture is understood as a pathfinder for Chinese economy abroad" [25:70].

Fourthly, China portrayed itself as a responsible power concerned about global issues such as environmental protection and sustainability. By including CCY events demonstrating the PRC's cooperation with each target country in finding solutions to, for instance, renewable energy, China depicted itself as a growing, responsible super power that is aware of global concerns and strives for future sustainable development. The fourth strategic national image transmitted can thus be said to portray China's focus on “sustainable development.”

These results clearly support the claim that the party-state transmitted strategic narratives of self-presentation to European citizens through national images. I therefore argue that the PRC communicated at least four specific national images 
through the European China Culture Year festivals analyzed, namely, (1) China's sophisticated "high culture," which is "on par” with European high culture; (2) “cultural unity” among ethnic Chinese citizens; (3) China’s "innovativeness” and progressiveness; and (4) its efforts to achieve "sustainable development." A summary of the structural and conceptual approaches as well as underlying national images identified is illustrated in Figure 2 below.

Figure 2: China’s China Culture Year Strategy

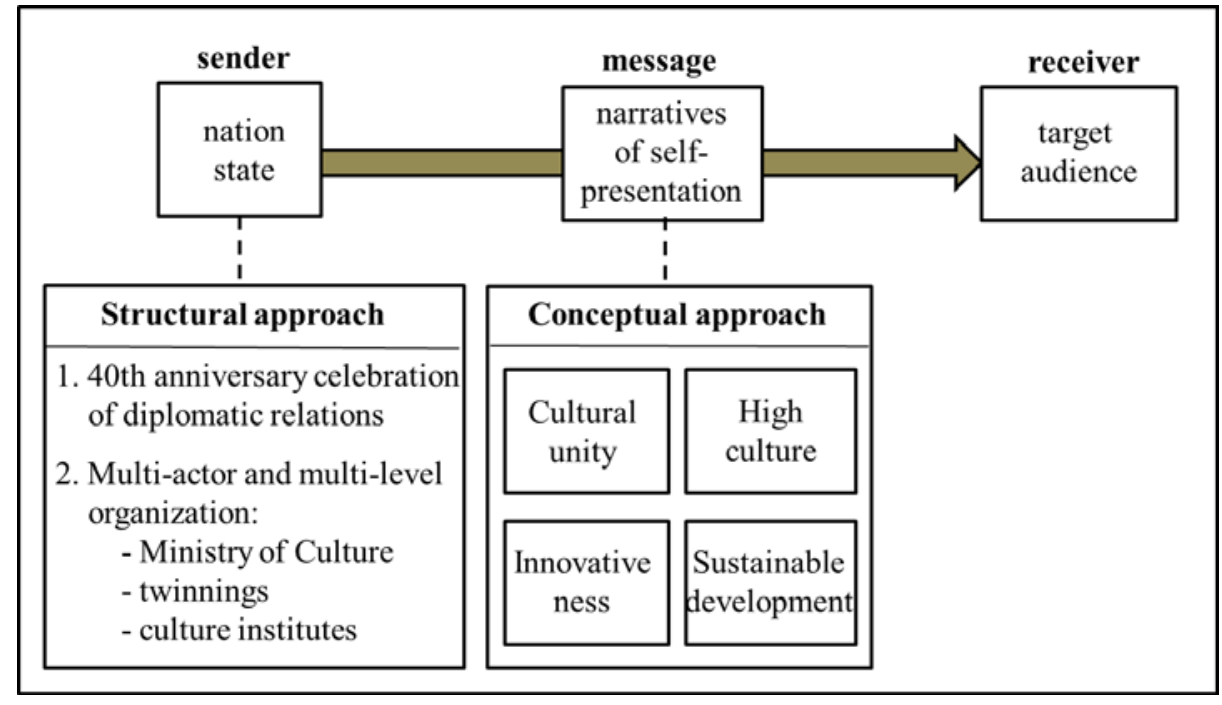

Source: Christina Maags

\section{Will Chinese culture do the trick?}

The PRC's strategy of concentrating on its cultural and economic resources in order to accumulate soft power has strengths and weaknesses. It is advantageous for the PRC to rely on cultural and economic resources, as states fare best when they choose soft-power assets in which they have a comparative advantage [74:16]. Europeans have a favorable opinion about Chinese culture and also benefit to some extent from the economic relations between Europe and China [13:175]. Therefore, when cultural events are selected on the basis of local tastes and exclude sensitive content, the party-state makes maximum use of its resources since Chinese culture is presented in the most positive way possible. For these reasons, the promotion of Chinese cultural national images can be regarded as the PRC's most promising approach to discrediting the "China threat theory” and accumulating soft power.

The promotion of Chinese culture in general also promises benefits in other areas, since this could intensify interest in Chinese cultural products, thereby resulting in 
greater profit for China's creative industries [29:34]. Also, opportunities to cooperate with foreign governments on cultural issues could support state-level diplomatic relations between the countries through enhanced interstate contact. Finally, popularizing China's culture could further be beneficial for making classical Chinese history and thought more visible and understandable to European citizens [13:168]. However, one must keep in mind that this knowledge does not necessarily lead to less criticism of Chinese politics by the European public.

Despite these potential advantages, the impact of China's cultural diplomacy remains limited. Given the PRC's negative political national image, advancements made in the cultural realm can be immediately demolished through negative press about the Chinese political system [75:107]. Since the European public has demonstrated a great interest in domestic Chinese politics and has often voiced severe criticism (i.e., the Tibetan riots in 2008), it could regard the China Culture Years as being "officially orchestrated" by the party-state and thus proof of its authoritarian character. The public diplomacy activities of the party-state are frequently gauged as "lacking credibility," so that their effect is confined by political activities [15:302]. Also the strategy to jointly advertise the cultural and economic national image could prove to be disadvantageous since China's economy is also associated with negative impacts. Examples include the growing trade imbalance on the part of European countries with the PRC [12:148], the flooding of markets with cheap Chinese products, and job losses among the European labor force as companies move production facilities to China [8:86]. Last but not least, although the PRC does not represent a direct security threat to Europe, its growing military expenditure does concern European citizens [76:10] and undermines the Chinese claim of striving for harmony.

\section{Conclusion}

Since the mid-2000s the Chinese party-state has invested heavily in developing its cultural diplomacy capacities worldwide. New public diplomacy institutions and think tanks, the construction of Confucius Institutes and China Culture Centers, and the expansion of bilateral cultural ties have all been attempts to promote Chinese culture abroad. This paper has focused on China Culture Years in Europe as an example of China's cultural diplomacy strategy in order to identify how the PRC 
organizes such events and which strategic narratives of self-presentation it transmits through the cultural events on display.

The data derived from the CCY programs suggests that the party-state utilizes a common strategy to initiate and organize the cultural events, relying particularly on the local expertise of Confucius Institutes, China Culture Centers and twin-city partnerships in the target country. The analysis of the program content has revealed that all programs analyzed were constructed by grouping additional content around a set of core events. Here varying blends of traditional and contemporary "high culture” were highlighted. In addition, the organizers included events that depicted China's innovativeness and sustainable development in two of three European cases. To optimize the impact of the festival, the party-state also selected country-specific events in order to make the festival as appealing as possible to the local audience.

A subsequent qualitative analysis of the events provided insights into which national images and narratives of self-presentation the party-state attempted to transmit. Through the comparison of the European cases with the Australian case, the author has identified four strategic national images, each representing a narrative of its own. By focusing on "high culture" events often associated with Western culture, the PRC attempted to present itself as a culturally well-developed state equal to Western powers. This narrative was supported by theme names such as "Eternal China," which glorified the Chinese empire and staked a claim for civilizational superiority. A second cultural national image was also identifiable, namely, China's "cultural unity.” However, since the PRC only portrayed Han Chinese culture, the organizers avoided the possibility of audience associations regarding domestic conflicts with minorities. In consequence of this omission, the party-state presented an orchestrated narrative of a harmonious and unified culture. The incorporation of technological events communicated the third national image: that of China's "innovativeness," which is comparable to Western standards. Finally, by referring to its progress in research on environmental protection measures China portrayed itself, fourth, as a responsible power striving for "sustainable development."

Despite these strategic national images, all of which contain an elaborate narrative presenting China in a most favorable way, the CCYs may not have yielded the benefits the party-state hoped for. Negative political and economic national images as well as Chinese military growth will most likely continue to hamper the impact of 
Chinese cultural diplomacy in Europe. Nevertheless, an analysis of China's cultural diplomacy strategies and inherent narratives is imperative in order to obtain a deeper knowledge of how and with which means the party-state is attempting to promote its culture to the European audience. Only by examining the images and narratives behind Chinese cultural diplomacy activities can the party-state’s "Charm Offensive” be holistically grasped and understood. 


\section{References:}

${ }^{1}$ Roy, Denny. 1996. The "China Threat" Issue: Major Arguments, Asian Survey, 36 (8), 758-77.

2 Nye, Joseph. 2004. Soft Power: The Means to Success in World Politics. Public Affairs.

${ }^{3} \mathrm{Li}$, Mingjiang. 2009. Soft Power in the Chinese discourse. Popularity and Prospects. In: Li, Mingjiang. ed. 2009. Soft Power. China's Emerging Strategy in International Politics. Lanham: Lexington Books, 21-44.

4 Weigl, Aron. 2004. Auswärtige Kulturpolitik der Volksrepublik China. Saarbrücken: AV Akademiker Verlag.

${ }^{5}$ Ding, Sheng. 2008. To Build A “Harmonious World”: China’s Soft Power Wielding in the Global South, Journal of Chinese Political Science, 13 (2), 193-213.

${ }^{6}$ Niquet, Valerie. 2012. 'Confu-Talk'. The use of Confucian concepts in contemporary Chinese foreign policy. In: Brady, Anne-Marie. ed. 2012. China’s Thought Management, 57-75.

${ }^{7}$ Kurlantzick, Joshua. 2007. Charm Offensive. How China's Soft Power is Transforming the World. New Haven: Yale University Press.

${ }^{8}$ Xin, Li and Verner Worm. 2011. Building China’s Soft Power for a Peaceful Rise. Journal of Chinese Political Science, 16 (1), 69-89.

${ }^{9}$ Gill, Bates and Yanzhong Huang. 2006. Sources and Limits of Chinese Soft Power, Survival, 48 (2), 17-36.

${ }^{10}$ Garrison, Jean. 2005. China's Prudent Cultivation of "Soft" Power and Implications for U.S. Policy in East Asia. Asian Affairs, 32 (1), 25-30.

${ }^{11}$ McGiffert, Carola. eds. 2009. Chinese Soft Power and Its Implications for the United States. Washington D.C.: Center For Strategic and International Studies.

12 Heilmann, Sebastian and Dirk Schmidt. 2012. Außenpolitik und Außenwirtschaft der Volksrepublik China. Springer Verlag für Sozialwissenschaften.

${ }^{13}$ D’Hooghe, Ingrid. 2011. The Limits of China’s soft power in Europe. In: Lee, Sook Jong and Jan Melissen. 2011. Public Diplomacy and Soft Power in East Asia. New York: Palgrave McMillan, 163190.

14 Boulding, Kenneth. 1959. National Images and International Systems. Journal of conflict resolution, 3 (2), 120-131.

${ }^{15}$ Dinnie, Keith. 2008. Nation Branding. Concepts, Issues, Practice. Oxford: Butterworth-Heinemann.

16 Tuch, Hans. 1990. Communicating with the world: US public diplomacy overseas. New York: St. Martin's Press.

17 Gonesh, Ashvin and Jan Melissen. 2005. Public diplomacy: Improving practice. Clingendael Diplomacy Papers No.5, The Hague: Netherlands Institute of International Relations.

${ }^{18}$ Cull, Nicholas. 2008. Public Diplomacy, Taxonomies and Histories. The ANNALS of the American Academy of Political and Social Science, 616 (10), 31-54.

${ }^{19}$ Aoki-Okabe, Maki; Toichi Makita and Yoko Kawamura. 2010. 'Germany in Europe’, 'Japan and Asia’: National Commitments to Cultural Relations in Regional Frameworks. In: Gienow-Hecht, Jessica and Mark Donfried. 2010. Searching for a Cultural Diplomacy. Oxford: Berghahn Books. 
${ }^{20}$ Schneider, Cynthia. 2003. Diplomacy That Works: Best Practices in Cultural Diplomacy. Cultural Diplomacy Research Series, Center for Arts and Culture, 1-16.

21 Zaharna, R.S. 2007. The Soft Power Differential: Network Communication and Mass Communication in Public Diplomacy. The Hague Journal of Diplomacy, 2 (3), 213-228.

22 Gienow-Hecht, Jessica and Mark Donfried. 2010. Introduction: Searching for a Cultural Diplomacy. In: Gienow-Hecht, Jessica and Mark Donfried. 2010. Searching for a Cultural Diplomacy. Oxford: Berghahn Books.

${ }^{23}$ Guo, Kailiang. 2011. Cultural heritage protection and the promotion of soft power (wénhuà yíchăn băohù yǔ ruăn shílì tíshēng). In: Provincial Leadership Forum (Shěngbù lǐngdăo lùntán), 11, 17-19.

${ }^{24}$ Liu, Hongshui. 2009. Discussing China’s special socialist cultural softpower (lùn zhōngguó tèsè shèhuì zhǔyì wénhuà ruăn shílì). In: Theory Journal (lì̌ùn xué kān), 11, 107-110.

${ }^{25}$ Hartig, Falk. 2012. Confucius Institutes and the Rose of China. Journal of Chinese Political Science, 17, 53-76.

${ }^{26}$ Starr, Don. 2009. Chinese Language Education in Europe: Confucius Institutes. European Journal of Education, 44 (1), 65-82.

${ }^{27}$ Paradise, James. 2009. China and International Harmony: The Role of Confucius Institutes in Bolstering Beijing's. Asian Survey, 49 (4), 647-669.

${ }^{28}$ Cheng, Xiaohe. 2009. Education: the intellectual base of China's soft power. In: Li, Mingjiang. 2011. Soft Power. China's Emerging Strategy in International Politics. Lanham: Lexington Books, 103-124.

${ }^{29}$ Zhang, Juyan and Glen T. Cameron. 2003. China’s agenda building and image polishing in the US: assessing an international public relations campaign. Public Relations Review, 29, 13-28.

${ }^{30}$ Deng, Xiaogang and Lening Zhang. 2003. China’s Cultural Exports and its Growing Cultural Power in the World. In: Li, Mingjiang. 2011. Soft Power. China's Emerging Strategy in International Politics. Lanham: Lexington Books, 143-163.

${ }^{31}$ Meissner, Werner. 2002. Cultural Relations between China and the Member States of the European Union. The China Quarterly, 169, 181-203.

32 Sofield, Trevor and Fung Mei Sarah Li. 1998. Tourism and cultural policies in China. Annals of Tourism Research, 25 (2), 362-392.

33 Institute of Asian Affairs. 2004. Timeline of Chinese-European Cultural Relations, online: http://www.bertelsmannstiftung.de/cps/rde/xbcr/SID-351589355DE1CC03/bst/Timeline_Chinese-

European_Relations.pdf (accessed: 26.12.2012)

${ }^{34}$ PRC Ministry of Culture. 2003. Administrative Provision of Foreign-Related Culture-and-art performances and exhibitions of the Ministry of Culture, online: http://www.chinaculture.org/gb/ en_customer/2003-09/25/content_43040.htm (accessed: 5.11.2012)

${ }^{35}$ PRC Ministry of Culture. 2003. Formulation and Development of External Cultural Exchange Policy, online: $\quad$ http://www.chinaculture.org/gb/en_exchange/200309/24/content_36939.htm (accessed: 17.11.2012)

${ }^{36}$ Wang, Jian. 2011. Introduction: China’s Search of Soft Power. In: Wang, Jian. 2011. Soft Power in China. Public Diplomacy through Communication. New York: Palgrave MacMillan, 1-18. 
${ }^{37}$ CPC Central Committee (2011): DECISION OF THE CPC CENTRAL COMMITTEE ON MAJOR ISSUES PERTAINING TO DEEPENING REFORM OF THE CULTURAL SYSTEM AND PROMOTING THE GREAT DEVELOPMENT AND FLOURISHING OF SOCIALIST CULTURE, 2011, online: http://www.cctb.net/bygz/wxfy/201111/t20111117_30877.htm (accessed: 9.11.2012)

${ }^{38}$ Brady, Anne-Marie. 2006. Guiding Hand: The Role of the CCP Central Propaganda Department in the Current Era. Westminster Papers in Communication and Culture, 3 (1), 58-77.

${ }^{39}$ Government of the PRC. 2012. Organizational Structure under the State Council, online: http://english.gov.cn/links.htm\#1 (accessed: 20.6.2013)

${ }^{40}$ People's Daily. 2010. Public diplomacy: New luminance color of Chinese diplomacy, online: http://english.peopledaily.com.cn/90001/90776/90883/7125349.html

41 PRC Ministry of Culture. 2009. Bureau of external cultural relations, online: http://www.ccnt.gov.cn/English/jgsz/bjg/200904/t20090428_62710.html (accessed: 17.12.2012)

${ }^{42}$ Zhang, Junhua, Katrin Willmann and Ursula Dreikosen. 2005. „Kulturwirtschaft“- das letzte Stück Kuchen der Reform- Eine kritische Betrachtung der chinesischen Kulturpolitik und deren Praxis im Prozess der Globalisierung. China aktuell, 6, 25-39.

${ }^{43}$ Chinese People's Association for Friendship with Foreign Countries. 2013. About us, online: http://en.cpaffc.org.cn/introduction/agrintr.html (accessed: 11.8.2013)

${ }^{44}$ China International Cultural Association. 2013. China International Cultural Association, online: http://www.cica.org.cn/portal/pubinfo/002001/20120928/35f1430aff5149a1adc14cdce3f4e086.html (accessed: 18.6.2013)

${ }^{45}$ Hanban. 2013. The Joint Conference of Confucius Institutes in Europe of 2013 is Convened in Italy, online: http://english.hanban.org/article/2013-06/09/content_499039.htm (accessed 6.8.2013)

${ }^{46}$ China Culture Center web. 2010. About us, online: http://www.cccweb.org/en/whzxjs/zxjj/index. shtml, (accessed: 3.6.2013)

${ }^{47}$ German CCY. 2012. ALLGEMEINE INFORMATIONEN, online: http://www.cn2012de.com/ deabout.aspx (accessed 6.12.2012)

48 French China.org. 2003. Présentation, online: http://french.china.org.cn/french/85978.htm (accessed: 10.12.2012)

${ }^{49}$ Italian CCY. 2010. Anno Culturale della Cina in Italia, online: http://www.annoculturacinese.it/ (accessed:14.12.2012)

${ }^{50}$ China International Culture Exchange Center. 2005. About CICEC, online: http://www.cicec.org. $\underline{\text { cn/zhongxinjianjie_e.html (accessed: 6.8.2013) }}$

${ }^{51}$ China Culture Center web (2010): CCC (Paris), online: http://www.cccweb.org/en/whzxjs/ zwzgwhzx/4135.shtml (accessed 7.8.2013)

${ }^{52}$ French China.org. 2003. Exposition des peintures à l'huile de Liu Linghua à Paris, online: http://french.china.org.cn/french/98786.htm (accessed: 22.6.2013)

53 Asia - Europe Meeting. 2010. Mapping Asia-Europe cultural cooperation, online: http://culture360.org/wpcontent/blogs.dir/1/files/MappingAsiaEurope.pdf (accessed: 18.12.2012)

54 Xinhua. 2009. China-Italy Relations, online: http://news.xinhuanet.com/english/2009 05/12/ content_11359105.htm (accessed: 19.12.2012) 
55 Anhui News.org. 2011. Anhui Week to Debut in Italy, online: http://english.anhuinews.com/ system/2011/05/20/004057300.shtml (accessed: 9.8.2013)

${ }^{56}$ Fewsmith, Joseph. 2004. Promoting the Scientific Development Concept. In: China Leadership Monitor, 11, 1-10.

${ }^{57}$ German Ministry of Foreign Affairs. 2006. Abkommen zwischen der Regierung der Bundesrepublik Deutschland und der Regierung der Volksrepublik China über kulturelle Zusammenarbeit. Bundesgesetzblatt, II , 2, 36-40.

${ }^{58}$ German CCY. 2012. Alle Veranstaltungen, online: http://www.cn2012de.com/deactivityall.aspx (accessed: 9.12.2012)

${ }^{59}$ Department of Foreign Affairs and Trade of Australia. 2012. Australia-China Council. About us, online: http://www.dfat.gov.au/acc/ (accessed: 22.12.2012)

60 Australian Ministry of Arts. 2012. Australia and China sign cultural program, online: http://www.minister.regional.gov.au/sc/releases/2012/december/sc240_2012.aspX $\quad$ (accessed: 23.12.2012)

61 Australian CCY. 2011. Year of Chinese Culture in Australia 2011 - 2012, online: http://www.yearofchineseculture.com/content_common/pg-home-en.seo (accessed: 20.12.2012)

62 Australian CCY. 2011. Year of Chinese Culture in Australia 2011 - 2012, Events, online: http://www.yearofchineseculture.com/content_common/pc-events.seo (accessed: 23.12.2012)

63 Shambaugh, David. 2005. China Engages Asia: Reshaping the Regional Order. International Security, 29 (3), 64-99.

${ }^{64}$ German CCY. 2012. KONTAKT, online: http://www.cn2012de.com/decontact.aspx (accessed: 28.12.2012)

${ }^{65}$ Li, Qingben. 2012. Spreading culture abroad and national image building (duìwài wénhuà chuánbò yŭ guójiā xíngxiàng jiànshè). Hunan Social Sciences (Húnán shèhuì kē), 5, 1-5.

${ }^{66}$ Australian CCY. 2011. Tracking the Dragon, online: http://www.yearofchineseculture.com/content _common/pr-visual-arts_trackdragon-en.seo (accessed: 30.12.2012)

${ }^{67}$ Australian Embassy in the PRC. 2013. Trade and Investment, online: http://www.china.embassy. gov.au/bjng/relations2.html (accessed: 12.8.2013)

68 PEW Research Center. 2013. Opinion of China, online: http://www.pewglobal.org/database/ indicator/24/survey/15/ (accessed: 2.12.2012)

${ }^{69}$ Xinhua. 2011. "Experience China" cultural event to promote mutual understanding between China and Australia, online: http://news.xinhuanet.com/english2010/indepth/2011-04/06/c 13815519.htm (accessed 20.6.2013)

${ }^{70}$ D’Hooghe, Ingrid. 2007. The Rise of Chinese Public Diplomacy. Clingendael Diplomacy Papers, 12, The Hague: Netherlands Institute of International Relations.

${ }^{71}$ Barzun, Jacques. 2000. From Dawn to Decadence: 500 Years of Western Cultural Life 1500 to the Present. New York: HarperCollins.

${ }^{72}$ Callahan, William. 2004. National Insecurities: Humiliation, Salvation, and Chinese Nationalism. Alternatives: Global, Local, Political, 29 (2), 199-218. 
${ }^{73} \mathrm{Jia}$, Shaojun. 2004. On China’s cultural image (guānyú guójiā wénhuà xíngxiàng). Fiction Review (xiăoshuō pínglùn), 3, 10-14.

${ }^{74}$ Lee, Sook Jong. 2011. The Theory and Reality of Soft Power: Practical Approaches in East Asia. In: Lee, Sook Jong and Jan Melissen. 2011. Public Diplomacy and Soft Power in East Asia. New York: Palgrave McMillan, 139-163.

${ }^{75}$ Bieber, Linny. 2008. China in der deutschen Berichterstattung 2008. Eine multiperspektivische Inhaltsanalyse. Wiesbaden: VS Verlag für Sozialwissenschaften.

${ }^{76}$ BBC World Service Poll. 2011. Rising Concern about China's Increasing Power: Global Poll, online: http://www.globescan.com/commentary-and-analysis/press-releases/press-releases-2011/94press-releases-2011/132-rising-concern-about-chinas-increasing-powerglobal-poll.html (accessed: 11.12.2012) 